Article

\title{
Protein Engineering of Mung Bean (Vigna radiata (L.) Wilczek) 8S $\alpha$ Globulin with Lactostatin
}

\author{
Ma. Carla Gamis ${ }^{1,2, * \mathbb{D}}$, Lawrence Yves Uy ${ }^{3,4} \mathbb{D}^{\mathbb{D}}$, Antonio Laurena ${ }^{1,5}$, Wilma Hurtada ${ }^{1}$ and \\ Mary Ann Torio 1,3 \\ 1 Graduate School, University of the Philippines Los Baños, Jose R. Velasco Ave., Los Baños, Laguna 4031, \\ Philippines; aclaurena@up.edu.ph (A.L.); wahurtada@up.edu.ph (W.H.); motorio@up.edu.ph (M.A.T.) \\ 2 National Institute of Molecular Biology and Biotechnology, University of the Philippines Diliman, \\ Quezon City 1101, Philippines \\ 3 Institute of Chemistry, University of the Philippines Los Baños, Los Baños, Laguna 4031, Philippines; \\ lcuy1@up.edu.ph \\ 4 2nd Level, Science Heritage Building, Sibol St. DOST Compound, General Santos Avenue, Bicutan, \\ Taguig City 1631, Philippines \\ 5 Philippine Genome Center-Program for Agriculture, Livestock, Forestry and Fisheries, Office of the Vice \\ Chancellor for Research and Extension, UPLB, Los Baños, Laguna 4031, Philippines \\ * Correspondence: mlgamis@up.edu.ph
}

Received: 19 September 2020; Accepted: 3 November 2020; Published: 8 December 2020

\begin{abstract}
Mung bean is a well-known good source of protein. To increase its bioactivity, economic value, and nutritional content as a functional food and food additive, lactostatin (IIAEK), a cholesterol-lowering bioactive peptide, was engineered into mung bean $8 \mathrm{~S} \alpha$ globulin, a major storage protein. The results showed that the mutated $8 \mathrm{~S} \alpha$ globulin has a significant bile acid binding capacity (cholesterol-lowering activity) up to $47.25 \%$. Moreover, superimposed mutant (Mut2) and wild-type (Wt) 3D protein structures showed a 93-97\% identity, indicating that the mutant proteins are stable. Ultra-performance liquid chromatography(UPLC)-based assay showed similar retention time for wild-type and mutant protein samples. Both IIAEK peptide standard and Mut2 digest had comparable baseline peaks corresponding to the same molecular size based on the liquid chromatography-mass spectrometry (LC-MS) data. A 573.36-Da mass spectrum was seen in Mut2, which indicates that Mut2 8S $\alpha$ globulin has been successfully mutated and digested to release the bioactive peptide, IIAEK. In vitro bile acid binding capacity showed that the 6-h Wt and 12-h engineered protein (Mut2) digests had the highest activity. Lastly, potential allergenicity was checked in the Allergen Database for Food Safety (ADFS) and the AllerBase database, and the IIAEK peptide matched the Bos $\mathrm{d} 5$ epitopes. This study provides a strong foundation and basis for mung bean nutrition improvement, development of cholesterol-lowering food supplements, and protein engineering of other food proteins.
\end{abstract}

Keywords: lactostatin; mung bean; protein engineering; bioactive peptide

\section{Introduction}

The plant-based food diet has been actively promoted by health organizations to prevent chronic diseases [1]. One of these recommended plant-based foods is mung bean because it has various health benefits, such as angiotensin-converting enzyme inhibitory activity (ACE) [2]. Its seed is also a good source of protein since it contains $20.97-31.32 \%$ protein [3] and it is cultivated in many Asian countries as well as dry regions of southern Europe and warmer parts of Canada and the United States [1]. The globulins or storage proteins of mung bean are one of the most studied proteins. There are three types of globulins, namely the basic 7S, $8 \mathrm{~S}$, and 11S. Among these three, it was found that $8 \mathrm{~S}$ globulin 
(vicilin type) is the major storage protein in mung beans, having $89 \%$ of the protein component [4]. Although the mung bean is a good source of protein for consumption, it lacks sulfur-containing amino acids and other bioactivities [3,5].

To increase the economic value of the mung bean and its peptide isolates, several studies have been conducted to improve mung beans through protein engineering [6,7]. A study conducted by Dr. Prak et al. in 2006 [7] successfully induced multiple mutations in the variable regions of soybean proglycinin A1aBb1, leading to high yields (80\%) of a hypocholesterolemic pentapeptide, lactostatin (IIAEK), released during in vitro digestion with trypsin [7]. Due to the high sequence similarity of soybean proglycinin A1aB1b and mung bean vicilin (8S globulin), some studies have tried to apply the same techniques used in modifying soybean proglycinin $\mathrm{A} 1 \mathrm{aB} 1 \mathrm{~b}$ to introduce valuable amino acid variations in mung bean vicilin [8,9]. The mung bean vicilin has three isoforms, $8 \mathrm{~S} \alpha, 8 \mathrm{~S} \alpha^{\prime}$, and $8 \mathrm{~S} \beta$ [10]. $8 \mathrm{~S} \alpha$ globulin is a trimer consisting of three identical subunits [9]. Previous reports also showed that sulfhydryl groups and disulfide bonds can be introduced in the mung bean $8 \mathrm{~S} \alpha$ globulin using the site-directed mutagenesis approach of protein engineering. Their findings showed that the mutant $8 \mathrm{~S} \alpha$ globulin has improved structural stability compared to the non-transgenic counterpart [11]. In 2012, they conducted another study on mung bean vicilin, using the same approach to increase the number of methionine residues in the $8 \mathrm{~S} \alpha$ globulin, which not only improved the structural stability of the mutant protein but also improved the nutritional quality of the mung bean protein [12].

In this study, $8 \mathrm{~S} \alpha$ globulin was modified through protein engineering, leading to the expression and release of the hypocholesterolemic peptide, lactostatin (IIAEK). It is a well-studied bioactive peptide derived from a food protein, bovine $\beta$-lactoglobulin. Studies suggest that it has higher hypocholesterolemic activity than $\beta$-sinosterol (a cholesterol-lowering food additive) in rats [8]. Moreover, it decreased total serum cholesterol, very low density lipoprotein (VLDL) and low density lipoprotein (LDL) levels in hypercholesterolemic rats [8]. Aside from its known cholesterol lowering potential, IIAEK has also been identified to have potent angiotensin-converting enzyme (ACE) inhibitory activity in a tryptic hydrolysate of $\beta$-lactoglobulin [13].

\section{Materials and Methods}

\subsection{In Silico Modification and Modelling of Mutated $85 \alpha$ Globulin}

The amino acid sequence of mung bean $8 \mathrm{~S} \alpha$ globulin (ID: 2CV6) was downloaded from the Protein Data Bank [9]. The polypeptide chain is comprised of 424 amino acid residues. Substitution mutations were done in regions II, III, and IV. These portions of the amino acid sequence were identified as the disordered variable regions of the protein. For the first mutant, only region II was mutated (Mut2). The second mutant had mutations in both regions II and III (Mut23). Lastly, the third mutant had mutations in regions II, III, and IV (Mut234). Lysine residue was added in the N-terminal of the target IIAEK peptide because trypsin exclusively cleaves the C-terminal of arginine and lysine residues [14].

Using Swiss-model and Swiss PDB Viewer [15-17], 3D protein structure prediction and modeling were conducted, and the properties of the wild-type $(\mathrm{Wt})$ and the mutated $8 \mathrm{~S} \alpha$ globulin were compared, using 2CV6.1.A as a template. The superimposition of the protein structures was done using FATCAT [18]. Identity percentage refers to the number of sequences/characters that match exactly between the two proteins, while \% similarity is the degree of resemblance between the two structures being compared [19]. The prediction of the stabilizing effect of the mutated regions was done using DUET [20]. The DUET web server includes two computational techniques (mCSM and SDM-two free web servers under the University of Cambridge and the University of Melbourne used for mutation predictions) for analyzing missense mutations in proteins to generate a consensus prediction about the change in protein stability $(\Delta \Delta \mathrm{G})$ upon the introduction of the mutation, with the support of an optimized predictor using Support Vector Machines (SVM). The most stable structure (with mutations) based on the highest \% identity, \% similarity, and predicted stability was selected for in vitro mutagenesis. 


\subsection{Substitution Mutagenesis of IIAEK Residues}

The plasmid, pET-21d-8S $\alpha$ globulin (pET-21d(+) DNA-Novagen, Madison, Wisconsin, USA; catalog number: 69743), which is the cloning vector for $\mathrm{Wt}$ [21], was used as the template. Substitution mutations of IIAEK residues were introduced into the vector using the QuikChange ${ }^{\circledR}$ II site-directed Mutagenesis kit by Agilent, Santa Clara, California, USA (formerly Stratagene) (catalog number 200521). Primers were designed manually according to the guidelines given by the kit and sent out for synthesis. The amplified plasmids were transformed into the competent cells of XL1-Blue Supercompetent Escherichia coli cells (200236) using the heat-shock method. The plasmid was isolated using the PurLink Quick Plasmid Miniprep Kit (Invitrogen, Carlsbad, CA, USA) (K210010) and subjected to capillary DNA sequencing for confirmation of the mutated sites. The Wt and Mut2 plasmids were detected using $1 \%$ agarose via Mupid-2 plus submarine electrophoresis (AD110). Plasmid purity and concentration were checked using the Genesys 180 UV-Vis Spectrophotometer (Thermo Fisher Scientific, Waltham, MA, USA: 840-309000).

\subsection{Protein Expression}

The Mut2 plasmid was transformed into competent BL21 (DE3) E. coli cells (EC0114). Plasmid DNA was isolated and detected $1 \%$ agarose via gel electrophoresis. Then, $50 \mathrm{~mL}$ of Luria-Bertani (LB) broth (ThermoFischer, Waltham, Massachusetts, USA: 10855001) with ampicillin (Sigma-Aldrich, St. Louis, Missouri, USA: A0166) was inoculated with $200 \mathrm{uL}$ of transformed BL21 (DE3) E. coli cells and incubated for $16-18 \mathrm{~h}$ at $37^{\circ} \mathrm{C}$ with continuous shaking. Next, $5 \mathrm{~mL}$ of the overnight culture was inoculated in $100 \mathrm{~mL}$ of LB broth containing ampicillin and incubated at $37^{\circ} \mathrm{C}$ for $3-4 \mathrm{~h}$ or until $\mathrm{OD}_{600}$ of about 0.4 to 0.8 . Isopropyl- $\beta$-D-thiogalactopyranoside (IPTG) (Sigma-Aldrich: 15502) was added to the culture at a final concentration of $1 \mathrm{mM}$. The cells were grown further for $72 \mathrm{~h}$ at $25^{\circ} \mathrm{C}$. Cells were collected by centrifugation at $6000 \mathrm{rpm}$ for $15 \mathrm{~min}$ at $25^{\circ} \mathrm{C}$. The cells were re-suspended in $10 \mathrm{~mL}$ buffer A ( $35 \mathrm{mM} \mathrm{K}$-phosphate, $0.4 \mathrm{M} \mathrm{NaCl}, 1 \mathrm{mM}$ EDTA) and sonicated for $5 \mathrm{~min}$. After sonication, the supernatant was obtained and transferred into a clean 15-mL Falcon tube and immediately stored at $-20{ }^{\circ} \mathrm{C}$ to avoid degradation. The protein content of the samples was determined using the Bradford method [22]. Standard solutions of $0,2,5,10,15,20$, and $25 \mu \mathrm{g} / \mathrm{mL}$ bovine serum albumin (BSA) was prepared by mixing the necessary amount of protein from the stock solution $(1 \mathrm{mg} / \mathrm{mL})$ of BSA, buffer A, and Bradford reagent (Sigma Aldrich, St. Louis, MI, USA: B6916). The absorbance of the standards and samples at $595 \mathrm{~nm}$ was measured using a spectrophotometer.

\subsection{Protein Characterization}

The samples were subjected to SDS-PAGE (Mini-PROTEAN electrophoresis System-Bio-Rad: 1658004) according to the method of Laemmli (Biorad, Hercules, California, USA: 1610747) (1970) [23]. Ten microliters of sample were mixed with the same amount of the sample buffer. The resulting mixture was then heated in a boiling water bath for $5 \mathrm{~min}$. An appropriate amount of the heated sample mixture was loaded onto the wells of the gel. The samples were run in an $11 \%$ acrylamide resolving gel (0.375 $\mathrm{M}$ Tris- $\mathrm{Cl}, \mathrm{pH} 8.8)$ and $4 \%$ stacking gel $(0.125 \mathrm{M}$ Tris- $\mathrm{HCl}, \mathrm{pH} 6.8)$ along with the protein marker. Electrophoresis was carried out at $110 \mathrm{~V}$ for $80-90 \mathrm{~min}$. The gel was stained overnight using 0.05\% Coomassie Brilliant Blue R-250 (20278) and was then de-stained using an aqueous solution of methanol (Merck, Kennilworth, NJ, USA: 106012) and acetic acid (Merck, Kennilworth, NJ, USA: 100056) until the bands appeared to be distinct.

\subsection{Protein Purification}

Ammonium sulfate (0.81 g) (Merck, Kennilworth, NJ, USA: 7783-20-2/101217) was added to the crude protein extract $(4 \mathrm{~mL})$ to $35 \%$ saturation and was subjected to hydrophobic interaction chromatography (HIC) using Macro-Prep t-butyl Media (Biorad, Hercules, CA, USA) (156-0093). The sample was eluted with ammonium sulfate gradient of 35 to $0 \%$ saturation in buffer A. Fractions 
were subjected to sodium dodecyl sulfate-polyacrylamide gel electrophoresis [24], and those that contained the $\mathrm{Wt}$ and mutant $8 \mathrm{~S} \alpha$ globulin were pooled, further purified, and concentrated using Amicon ${ }^{\circledR}$ Ultra-4 (UFC8010) (Merck KGaA, Darmstadt, Germany).

\subsection{Enzymatic Digestion (Trypsin)}

Samples were hydrolyzed using $1 \mathrm{mg} / \mathrm{mL}$ trypsin (ThermoFischer, Waltham, MA, USA: 25200056) with a 1:15 enzyme:sample ratio. Samples were hydrolyzed at different digestion times, such as 2, 6,12 , and $24 \mathrm{~h}$. Samples were boiled for $5 \mathrm{~min}$ and immediately refrigerated after each digestion to deactivate the enzyme.

\subsection{Densitometric Analysis}

After gel-scanning using the GelDoc Go Imaging System (BIO-RAD, Hercules, CA, USA), densitometric analysis of SDS-PAGE gels was performed using the gel analysis software TotalLab 1D 21 CFR (CLIQS) to determine the extent of the digested samples.

\subsection{Peptide Identification Using Liquid Chromatography-Mass Spectrometry (LC-MS)}

Samples were prepared $(0.1 \mathrm{mg} / \mathrm{mL})$ before analysis. Samples and chemically synthesized IIAEK peptide standard were eluted using a linear gradient at the flow rate of $0.150 \mathrm{~mL} \mathrm{~min}^{-1}$ of $0.1 \%$ trifluoroacetic acid (TFA) in $80 \%$ acetonitrile on reverse-phase C18 column (dimension: $2.1 \times 50 \mathrm{~mm}$ and particle size: $1.7 \mu \mathrm{m}$ ) ACQUITY Arc System, Waters, Milford, Massachusetts, USA. Solvent A (LITR134849363.) was composed of $0.1 \%$ TFA in distilled water. The gradient for the solvent system is provided in Table 1. The eluted sample peptide fragments and the IIAEK standard peptide were monitored and mapped at $214 \mathrm{~nm}$. With the use of liquid chromatography-mass spectrometry (LC-MS) (Waters ACQUITY, Milford, MI, USA), mass spectrometry was conducted right after UPLC-based peptide mapping to generate spectra for mass analysis and for validation of the presence of the IIAEK peptide.

Table 1. Solvent gradient system for UPLC-based peptide mapping of tryptic digests of wild-type (Wt) and mutant (Mut2) proteins.

\begin{tabular}{cccc}
\hline Time (min) & Flow Rate (mL/min) & \%A & \%B \\
\hline Initial & 0.2 & 98.00 & 2.00 \\
3.40 & 0.2 & 40.00 & 60.00 \\
3.63 & 0.2 & 100.00 & 0.00 \\
3.85 & 0.2 & 100.00 & 0.00 \\
\hline
\end{tabular}

\subsection{Bile Acid Binding Capacity using UPLC Method}

In vitro bile acid binding capacity was determined using the method of $\mathrm{Hu}$ et al. (2008) and Kongo-Dia-Moukala et al. (2011), with slight modifications [24,25]. Protein samples were prepared in a 1:8 sample to $2 \mu \mathrm{M}$ sodium taurocholate solution (Sigma Aldrich CAS number: 345909-26-4). The final concentration of digested proteins in the incubated solution was $0.1 \mathrm{mg} / \mathrm{mL}$. The positive standard (rosuvastatin) had $0.1 \mathrm{mg} / \mathrm{mL}$ and $1 \mathrm{mg} / \mathrm{mL}(w / v)$ concentration in the bile salt acid solution. Samples and positive standards were incubated for one hour at $37^{\circ} \mathrm{C}$ with shaking. After incubation, samples were centrifuged at $37^{\circ} \mathrm{C}$ with $15,000 \mathrm{rpm}$ for $30 \mathrm{~min}$. Sodium taurocholate solution was prepared using $50 \mathrm{mM}$ sodium phosphate (Merck: 567545), $\mathrm{pH}$ 6.5. Standards of sodium taurocholate were prepared using a stock solution of $2 \mu \mathrm{M}$ taurocholate and run in UPLC Waters with C18 column (dimension: $2.1 \times 50 \mathrm{~mm}$ and particle size: $1.7 \mu \mathrm{m}$ ) ACQUITY Arc System, Waters, with solvent 65:35 (methanol $0.04 \mathrm{~g} / \mathrm{dL}$ potassium diphosphate) and a flow rate of $0.15 \mathrm{~mL} / \mathrm{min}$ for $4 \mathrm{~min}$. The concentration of sodium taurocholate in the incubated samples was calculated using the calibration curve from the 
concentration and area of standards. The percentage of bound sodium taurocholate was calculated using the equation:

$$
\% \text { bile acid reduction }=\frac{\text { peak area }(\text { blank })-\text { peak area }(\text { sample })}{\text { peak area }(\text { blank })} \times 100
$$

\subsection{Test for Allergenicity Potential}

The Mut2 protein and identified IIAEK peptide were submitted to different databases, such as the Allergen Database for Food Safety (http://allergen.nihs.go.jp/ADFS/) [26], AllergenOnline (http://www. allergenonline.org/) [27], AllerBase (http://bioinfo.net.in/AllerBase/Home.html) [28], Allermatch (http: //allermatch.org) [29], UniProt (https://www.uniprot.org/blast/) [30], and Allergome (http://www. allergome.org/index.php) [31-33], to check for homologous sequences and possible risk for allergenicity.

\subsection{Statistical Analysis}

Values were expressed in mean and standard deviation. A two-tailed $t$-test was used to compare two groups of means with $\alpha=0.05$. This analysis was done using Microsoft Excel 2016 version.

\section{Results}

\subsection{In Silico Modification and Modelling of Mutated $8 S \alpha$ Globulin}

The superimposition of $\mathrm{Wt}$ and Mut2 structures resulted in the highest \% identity (97.23\%) and \% similarity $(98.49 \%)$, as shown in Table 2 .

Table 2. Similarity of superimposed wildtype and mutant protein structures.

\begin{tabular}{ccc}
\hline Superimposed Structures & \% Identity & \% Similarity \\
\hline Mut2, Wt & 97.23 & 98.49 \\
Mut23, Wt & 94.96 & 97.48 \\
Mut234, Wt & 93.95 & 96.73 \\
\hline
\end{tabular}

The wildtype (Wt) and mutant structures (Mut2, Mut23, and Mut234) were superimposed individually. The red layer indicates the wildtype structure while the blue layer indicates the mutant structure. It was observed that Mut2, Mut23, and Mut234 were structurally different from the Wt template, having 5, 11, and 12 positions that formed different secondary structures in the variable regions, as shown in Figures 1-3, respectively. Among the three superimposed structures, it can be inferred that mutations in variable region II had the least effect on the stability of the 3D structure of the protein. 


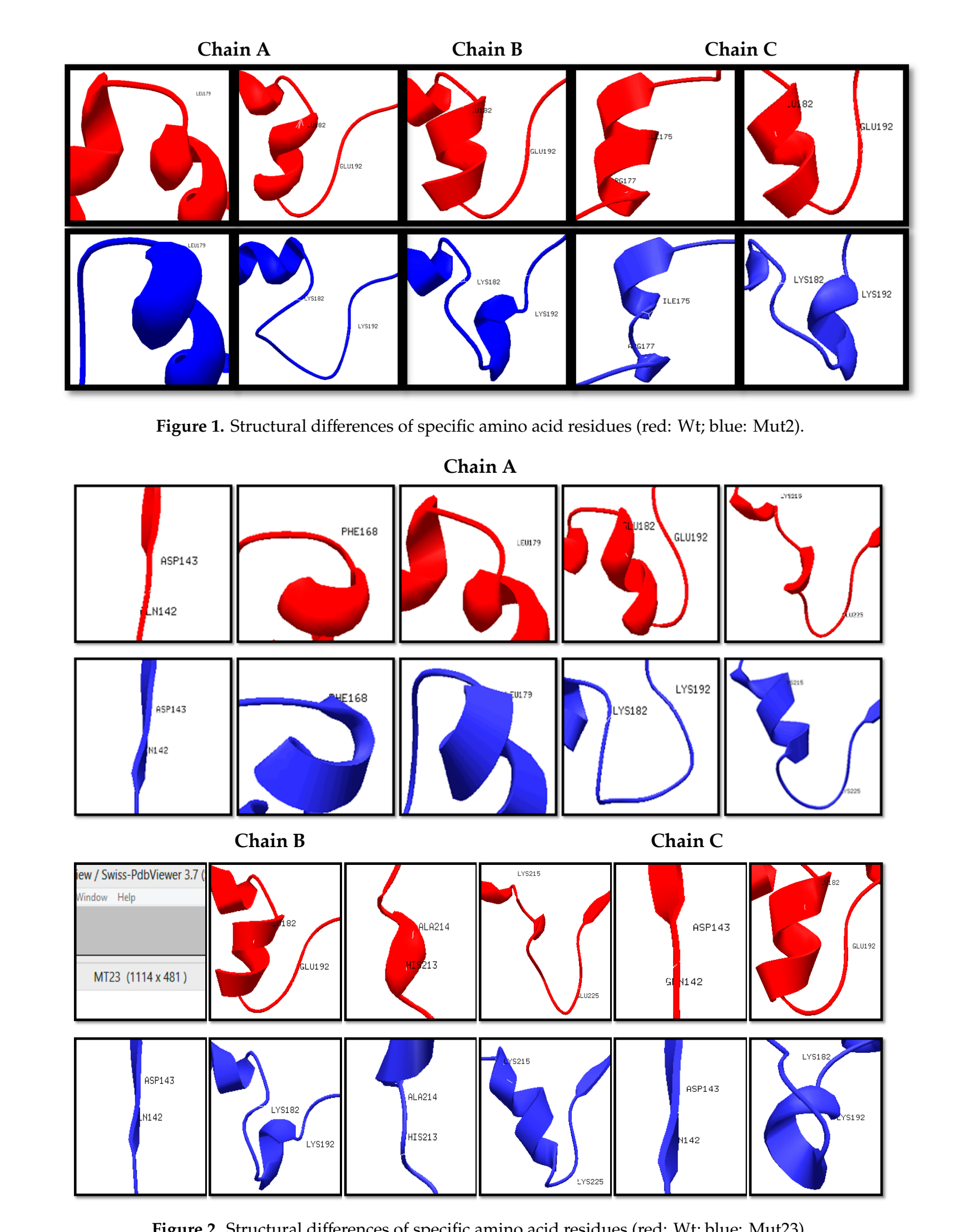


Chain A

Chain B
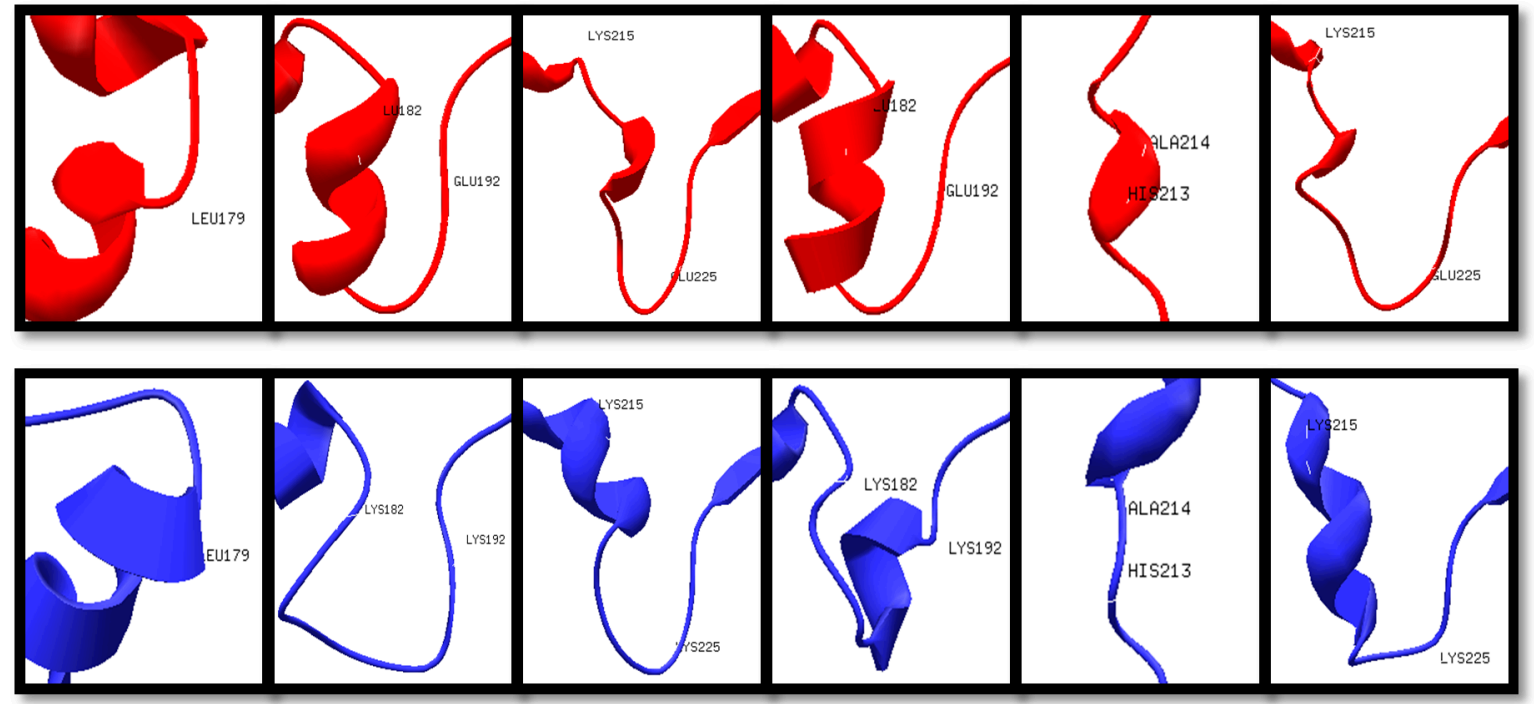

Chain B

Chain C
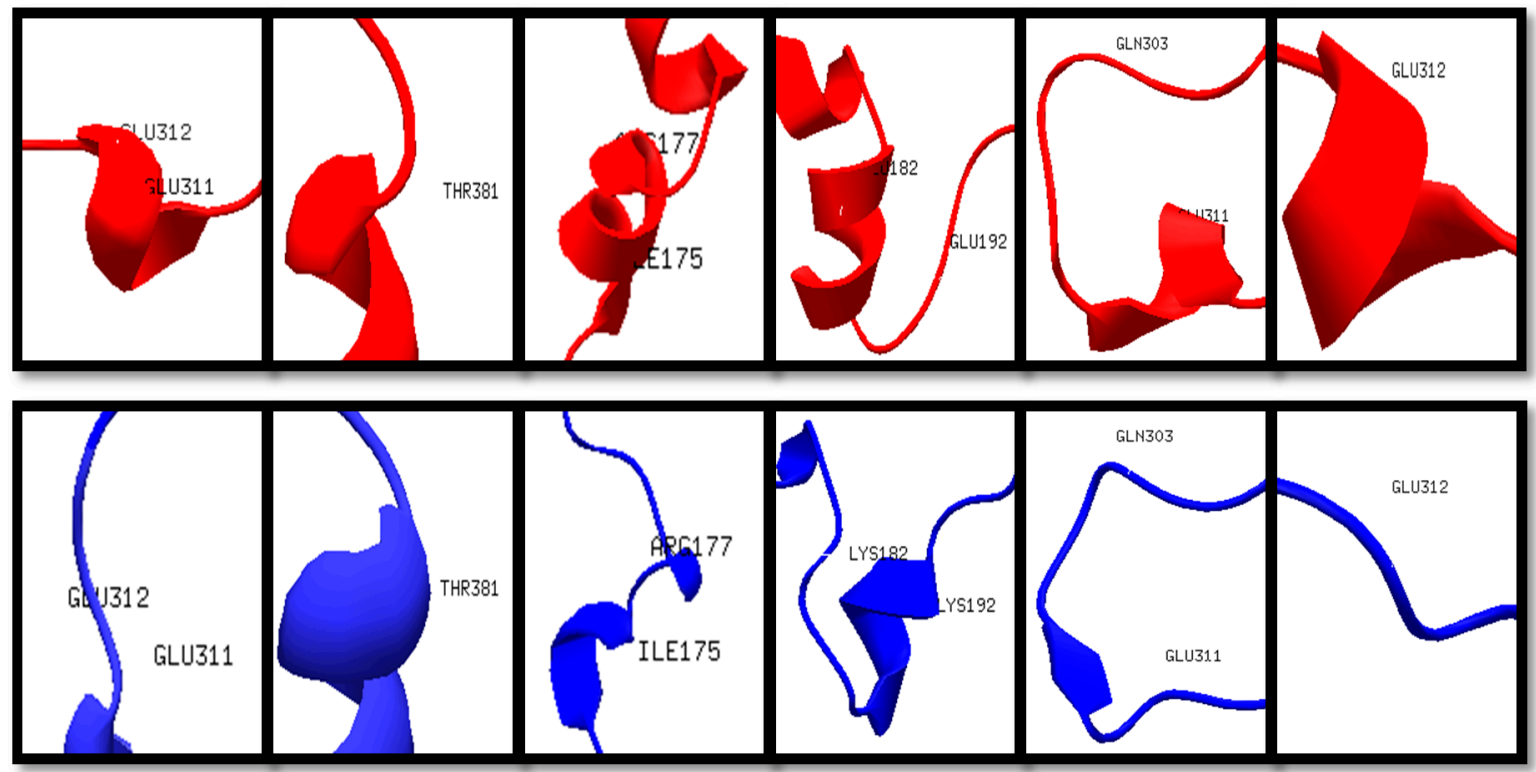

Figure 3. Structural differences of specific amino acid residues (red: Wt; blue: Mut234).

The in silico prediction of stabilizing effect showed that in region II, the mutations on positions 187, 190, and 191 had destabilizing effect according to their $\Delta \Delta \mathrm{G}$ values (Table S1). In region III, mutations on positions 216, 221, 222, 223, 224, and 225 showed destabilizing effects. Lastly, in region IV, only the mutations on positions 308 and 310 had destabilizing effects. The mutations in variable region II have shown the least destabilizing effect, which was consistent with the results in the 3D structure prediction and homology modeling. With these results, it can be inferred that mutagenesis is most stable in region II, specifically the first IIAEK sequence mutation.

\subsection{Substitution Mutagenesis of IIAEK Residues}

Using the guidelines provided by the QuikChange ${ }^{\circledR}$ II site-directed mutagenesis kit by Agilent for primer design, the desired mutation on the Wt plasmid was designed (Table 3). The red-colored letters indicate the point mutations on the template nucleotide sequence, as shown in the third column. The bold, italicized letters in the sixth column indicate the target mutation on the template amino acid sequence. 
Table 3. Primers designed to introduce desired modifications on the Wt plasmid.

\begin{tabular}{|c|c|c|c|c|c|}
\hline Seq. & Set & Primers & Translated Region & $\%$ GC & TM \\
\hline \multirow{5}{*}{ Mut2 } & & F1 (44) & & & \\
\hline & A & $\begin{array}{c}5^{\prime} \text {-gggttctgtttggaaagataatagcggagaaacagcaaggccag- } 3^{\prime} \\
\text { R1 (44) }\end{array}$ & VLFGKIIAEKQQGQ & 47.72 & 69.19 \\
\hline & & $5^{\prime}$-ctggccttgctgtttctccgctattatctttccaaacagaaccc-3' & & & \\
\hline & & F2 (45) & & & \\
\hline & B & $\begin{array}{c}5^{\prime} \text {-gataatagcggagaaataatagccgagaagagtcagcaagaggg-3' } \\
\text { R2 (45) } \\
5^{\prime} \text {-ccctcttgctgactcttctcggctattattttctccgctattatc- } 3^{\prime}\end{array}$ & IIAEKIIAEKSQQE & 44.44 & 68.18 \\
\hline
\end{tabular}

Using the primers of Mut2, the putative mutated plasmid (Mut2) was detected, having a molecular size of 6500 base pairs (Figure 4), as reported by Bernardo et al. (2004) [21]. Following the mutagenesis step, $D p n 1$ digestion of the amplification products was conducted to digest the non-mutated parental supercoiled dsDNA.

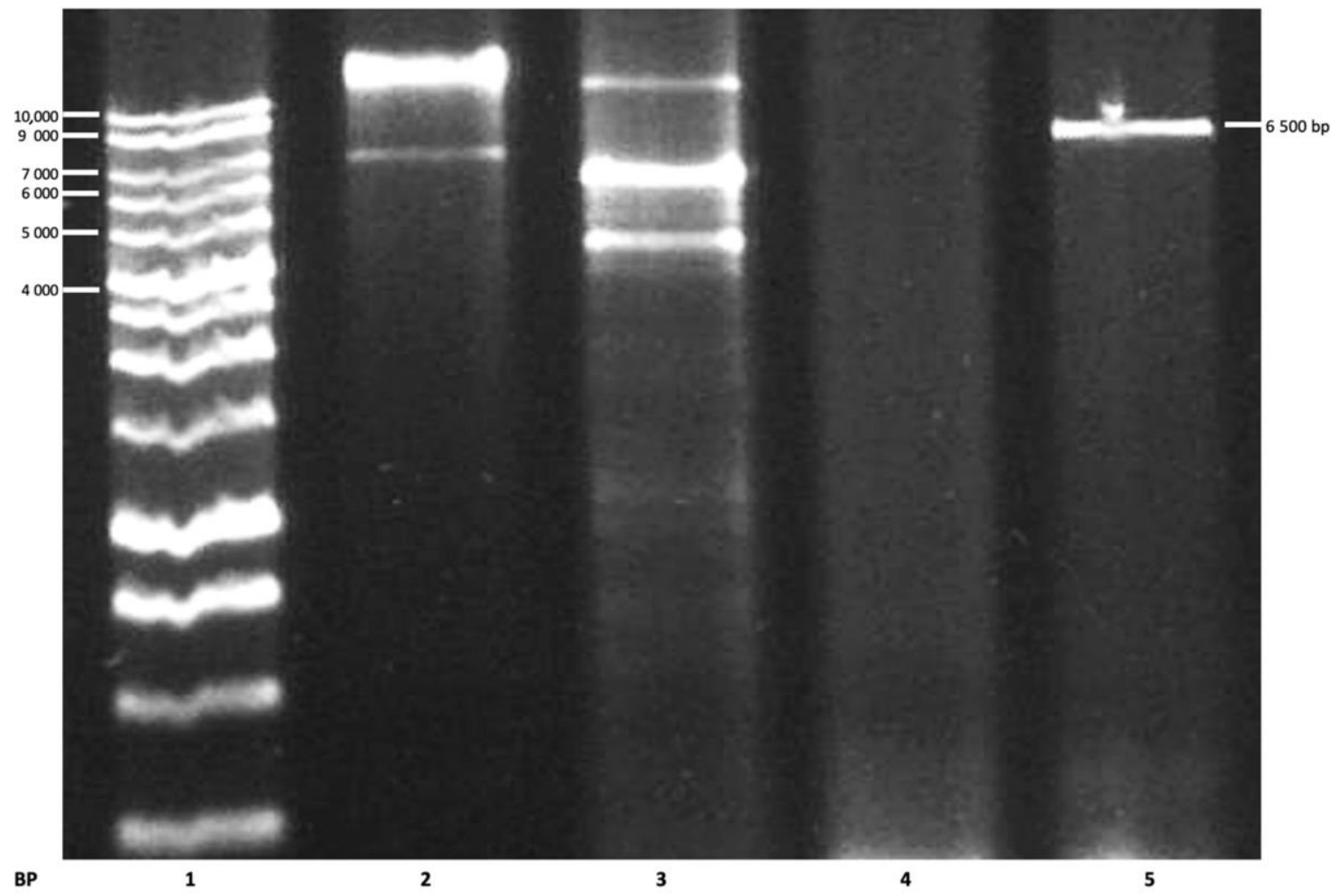

Figure 4. Electropherogram of the putative mutated plasmid. Lanes: 1, molecular weight ladder; 2 , Wt plasmid; 3, positive control; 4, negative control; 5, putative mutated plasmid (Mut2).

\subsection{Protein Content Determination and Characterization}

Protein was extracted from both Wt and Mut 2 cells. To determine the identity of the protein extracted, the samples were subjected to SDS-PAGE. The $8 \mathrm{~S} \alpha$ globulin, which is the major storage protein of mung bean, was reported to be a trimer of three identical subunits with a molecular weight of 49 KDa in SDS-PAGE [11,12,21]. Figure 5 shows that both Wt and Mut2 cells have expressed the target protein at $49 \mathrm{Kda}$. 


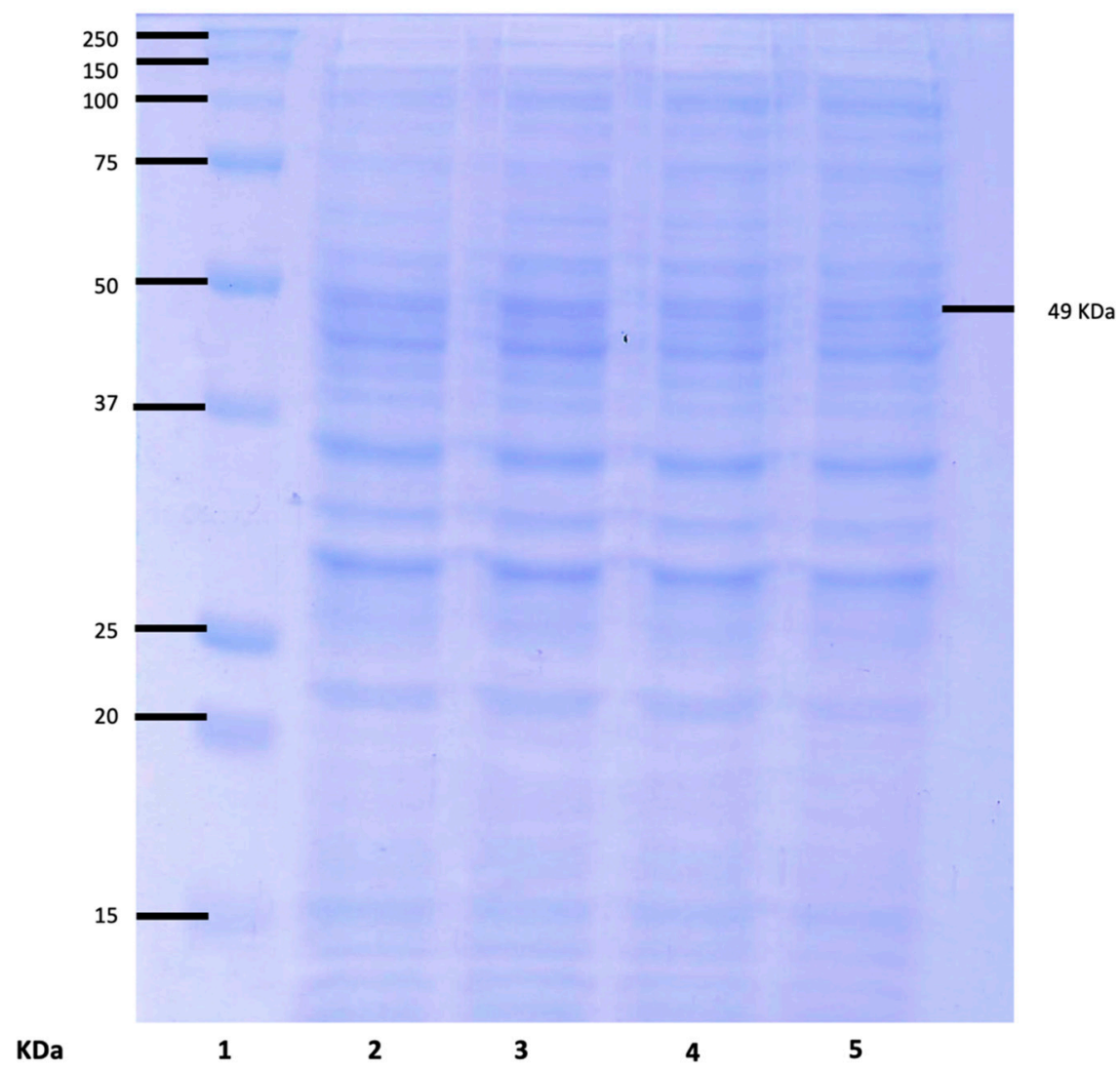

Figure 5. SDS-PAGE of crude Wt and crude Mut2 $8 \mathrm{~S} \alpha$ globulin. Lanes: 1, protein marker; 2 and 3, crude Wt $8 \mathrm{~S} \alpha$ globulin; 4 and 5, crude Mut2 $8 \mathrm{~S} \alpha$ globulin.

Using TotalLab 1D 21 CFR, densitometric analysis of the protein expression of the Wt and Mut2 $8 \mathrm{~S} \alpha$ globulin was conducted (Table 4). This shows that the expression of the Mut2 8S $\alpha$ globulin is only $6 \%$ less than that of the Wt $8 \mathrm{~S} \alpha$ globulin. In terms of overall expression in the crude protein, both Wt and Mut2 8S $\alpha$ globulin showed high expression. Torio et al. (2011) [11] also reported a high \% expression of the mutated $8 \mathrm{~S} \alpha$ globulin of up to $96 \%$.

Table 4. Comparison of protein expression in Wt and Mut2 $8 \mathrm{~S} \alpha$ globulin.

\begin{tabular}{ccc}
\hline Protein Sample & Percent (\%) Expressed & Percent (\%) Expressed/WT \\
\hline Wt & 8.35 & 100.00 \\
Mut2 & 7.82 & 93.65 \\
\hline
\end{tabular}

\subsection{Protein Purification}

Both Wt and Mut2 $8 \mathrm{~S} \alpha$ globulin were purified using ammonium sulfate precipitation and hydrophobic interaction chromatography [34]. As shown in Figure 6, two peaks were observed, the first peak having higher absorbance than the second peak. The Wt $8 \mathrm{~S} \alpha$ globulin (blue) had peaked at fraction numbers 11 and 23, while Mut2 $8 \mathrm{~S} \alpha$ globulin had peaked at fraction numbers 10 and 22. 


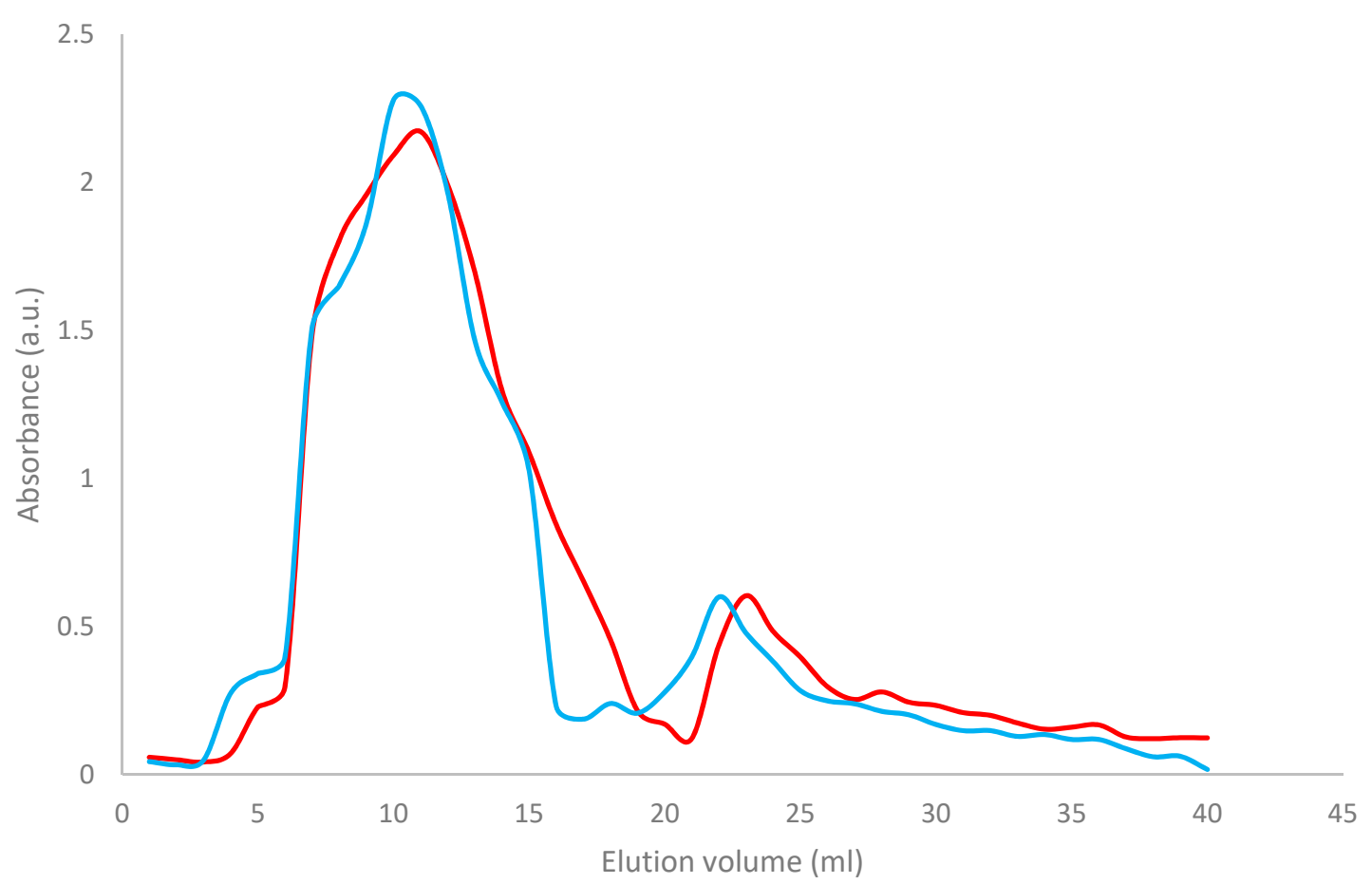

Figure 6. Elution profile of the Wt and Mut2 $8 \mathrm{~S} \alpha$ globulin after hydrophobic interaction chromatography (HIC) using Biorad butyl toyopearl. Red-Wt $8 \mathrm{~S} \alpha$ globulin; blue-Mut2 8S $\alpha$ globulin.

Table 5 shows the retention time and elution volume of Wt and Mut2 $8 \mathrm{~S} \alpha$ globulin in HIC, which showed that both samples had relatively the same HIC profile but there was a slight difference in the elution volume. In HIC, the longer the retention time, the more hydrophobic the sample; since the Wt $8 \mathrm{~S} \alpha$ globulin $(92 \mathrm{~min}$ ) and the Mut2 $8 \mathrm{~S} \alpha$ globulin $(88 \mathrm{~min}$ ) have almost the same retention time, it can be inferred that both proteins have the same level of hydrophobicity, thus having similar protein composition and structures.

Table 5. Retention time and elution volume of Wt and Mut2 $8 \mathrm{~S} \alpha$ globulin after HIC using Biorad butyl toyopearl.

\begin{tabular}{ccc}
\hline Type of Sample & Retention Time (min) & Elution Volume $(\mathbf{m L})$ \\
\hline Wt & 92 & 23 \\
Mut2 & 88 & 22 \\
\hline
\end{tabular}

\subsection{Trypsin Digestion}

Using Peptide Cutter [35], in silico trypsin digestion was conducted on the Mut2 amino acid sequence. Proteins were digested using $1 \mathrm{mg} / \mathrm{mL}$ trypsin at a 15:1 sample:enzyme ratio. Trypsin cleaves the carboxyl side of lysine and arginine, except when either of the amino acids is followed by a proline [14]. The in silico analysis, using Peptide Cutter software, of the digestion of the mutant $8 \mathrm{~S}$ globulin was done to determine the digestion sites and the peptides that were produced upon digestion. The lactostatin peptide (IIAEK) was released at position 187 near the C-terminal of the K residue at position 186.

Figures 7 and 8 show the SDS-PAGE of the undigested and digested Wt and Mut2 8S $\alpha$ globulin, respectively. Based on the intensity of the bands corresponding to the $49 \mathrm{kDa}$ protein of interest from the undigested, there is a decreasing concentration of the $8 \mathrm{~S} \alpha$ globulin as digestion progresses. Comparing the $\mathrm{Wt}$ and Mut2 digests, it is also notable to mention that the Mut2 digests had more intense bands compared to the Wt digests, considering both had the same concentration $(0.50 \mathrm{mg} / \mathrm{mL})$ among all digests. 


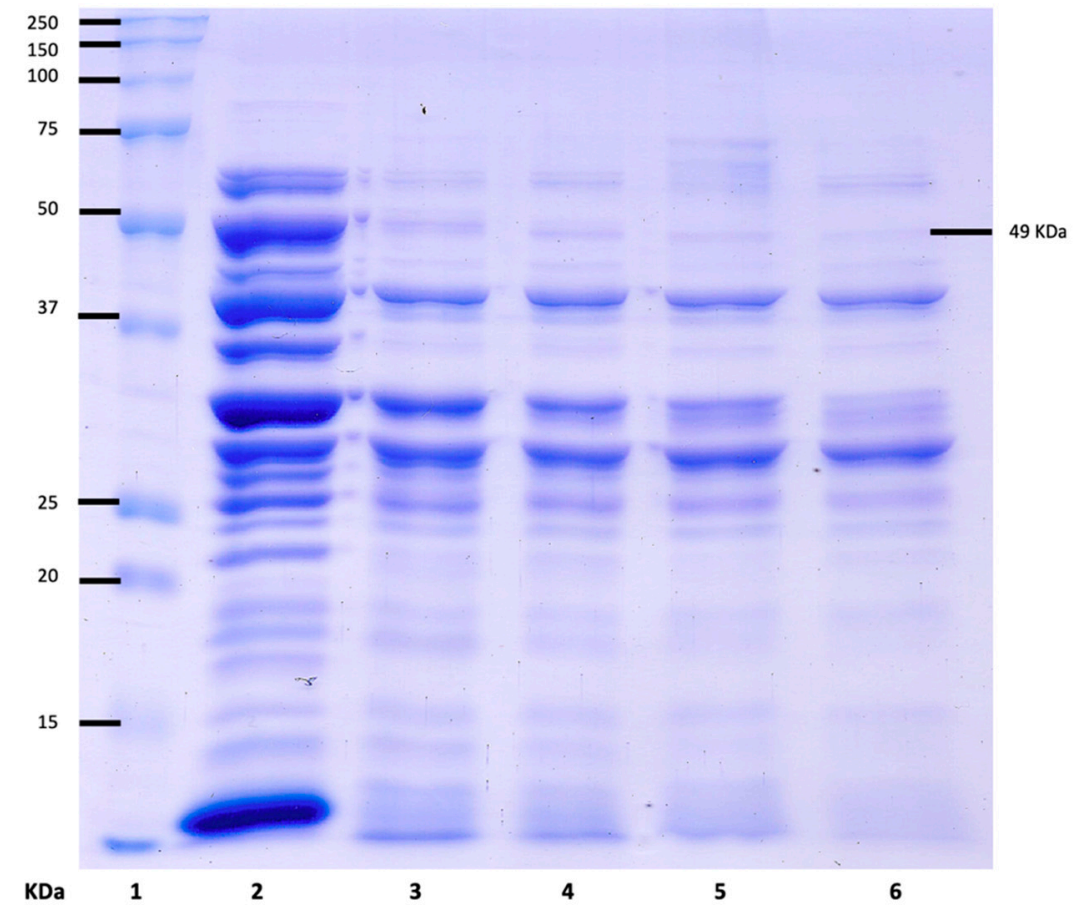

(A)

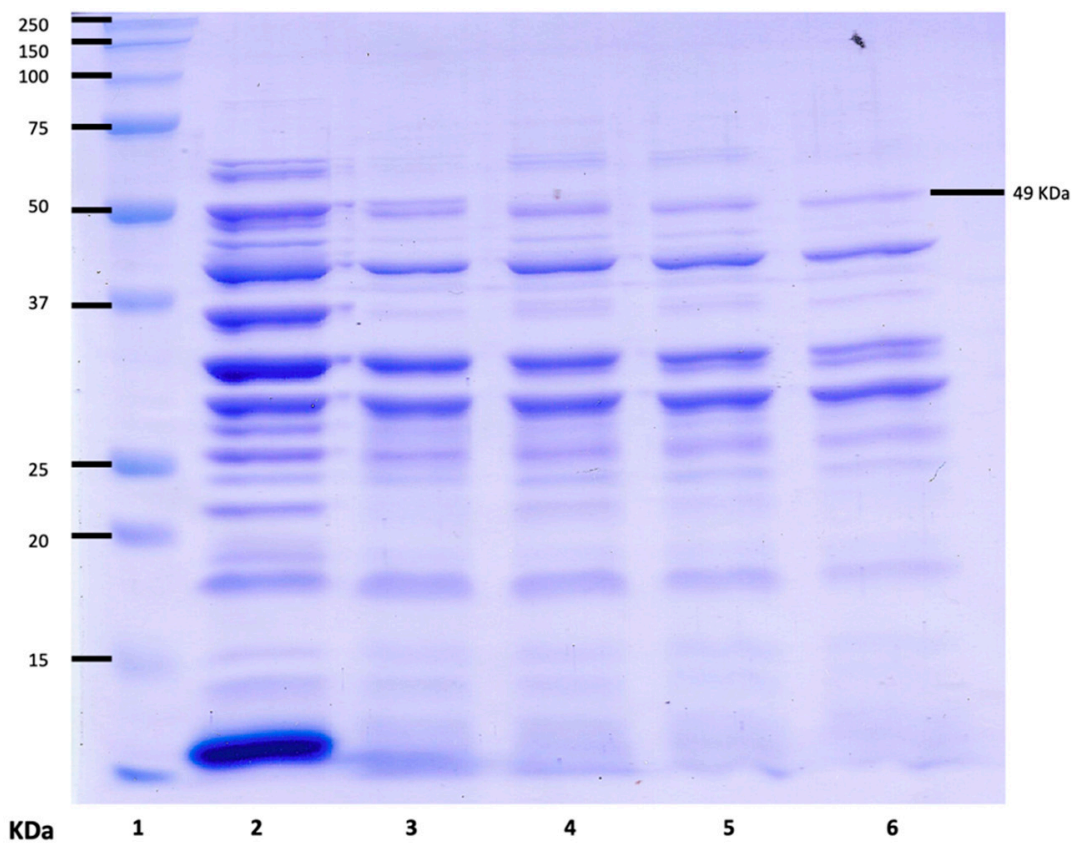

(B)

Figure 7. SDS-PAGE of undigested and digested (A) Wt $8 \mathrm{~S} \alpha$ globulin and (B) Mut2 $8 \mathrm{~S} \alpha$ globulin. Lanes-1: protein marker, 2: undigested sample, 3: 2-h digest, 4: 6-h digest, 5: 12-h digest, and 6: 24-h digest. 


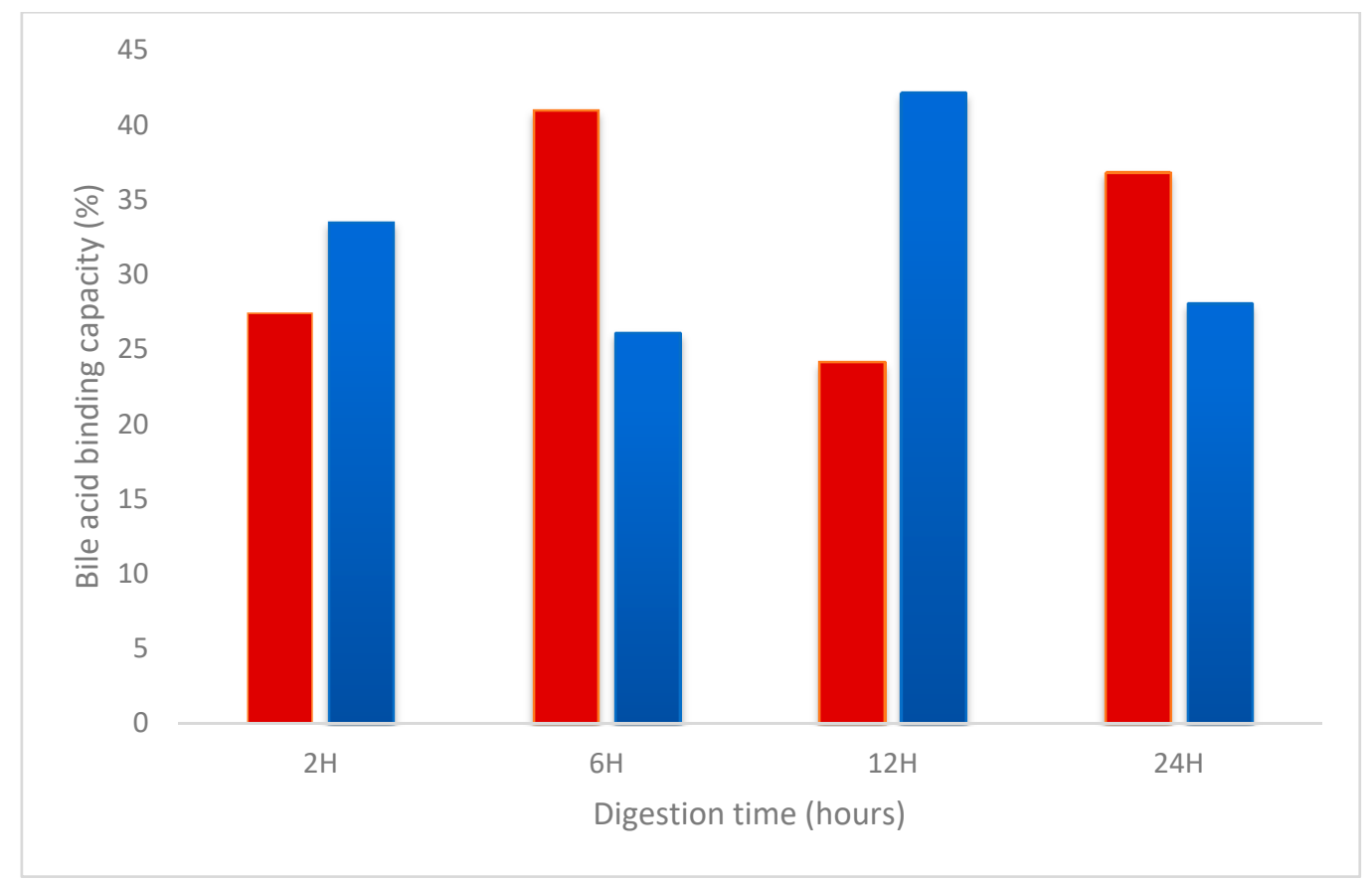

Figure 8. Bile acid binding capacity of Wt and Mut2 $8 \mathrm{~S} \alpha$ globulin digests. Red: Wt $8 \mathrm{~S} \alpha$ globulin digests; blue: Mut2 8S $\alpha$ globulin digests.

Densitometric analysis was conducted on both undigested and digested Wt and Mut2 8S $\alpha$ globulin proteins to further analyze the effect of digestion on the intensity of the bands corresponding to $49 \mathrm{kDa}$. In both analyses, the peak corresponding to the $49 \mathrm{kDa}$ band is decreasing as digestion hour lengthens. Consistent with the SDS-PAGE results mentioned previously, the peaks in Mut2 digests were higher than those of the Wt digests.

\subsection{IIAEK Detection and Identification}

To identify whether the IIAEK peptide was released during digestion, LC-MS of the 24-h Wt and Mut2 digests were conducted. The chromatogram result showed that similar to the IIAEK standard with approximately 573.36 Da that peaked at $2.94 \mathrm{~min}$, the 24-h Mut2 digest also has a baseline peak corresponding to the same molecular size at $3.12 \mathrm{~min}$ (Table 6). This peak was not found in the 24-h Wt digest (Figure S1). Furthermore, the baseline peaks of the standard and Mut2 digests were extracted to generate a mass spectrum of the fragments comprising the peaks. As shown in Table 6 (Figure S2), both the IIAEK peptide standard and the 24-h Mut2 digest had a similar spectrum of 573.36 Da, which indicates that Mut2 $8 \mathrm{~S} \alpha$ globulin has been successfully mutated and digested to release the bioactive peptide, IIAEK.

Table 6. Liquid chromatography-mass spectrometry (LC-MS) data of the 24-h Wt and Mut2 digests.

\begin{tabular}{cccc}
\hline \multirow{2}{*}{ Type of Sample } & \multicolumn{2}{c}{ Chromatogram Peak } & \multirow{2}{*}{ Mass Spectrum (Da) } \\
\cline { 2 - 3 } & Retention Time (min) & Molecular Size (Da) & \\
\hline IIAEK standard & 2.94 & 573.36 & 573.36 \\
24-h Wt digest & 3.07 & 496.78 & 496.78 \\
24-h Mut2 digest & 3.12 & 573.36 & 573.36 \\
\hline
\end{tabular}

\subsection{Bile Acid Binding Capacity}

Bile acid binding capacity (\%) was measured to determine the hypocholesterolemic activity of the purified Wt and Mut2 hydrolysates. Taurocholate, a known bile salt, was incubated with the samples 
and the controls. Rosuvastatin, a commercially available hypocholesterolemic drug was used as control. Figure 8 shows the \% reduction in the taurocholate incubated with the Wt and Mut2 hydrolysates. The 6-h Wt and 12-h Mut2 digests had the highest \% reduction of $40.97 \%$ and $42.12 \%$, respectively. A two-tailed $t$-test showed that only the $12-\mathrm{h} \mathrm{Wt}$ and Mut2 digests ( $p$-value $=0.03$ ) were significantly different from each other (Table S2). All samples had a higher \% reduction compared to the control, $0.1 \mathrm{mg} / \mathrm{mL}$ rosuvastatin. However, only the 6-h Wt $(p$-value $=0.05), 12-\mathrm{h} \mathrm{Wt}(p$-value $=0.05)$, and 12-h Mut2 $(p$-value $=0.04)$ digests were significantly different from the $0.1 \mathrm{mg} / \mathrm{mL}$ rosuvastatin control (Table S2).

\subsection{Allergenicity Potential}

The phenomenon wherein a specific antibody recognizes multiple allergens is called allergic cross-reactivity, which provides important information on allergic diseases and their diagnoses [36,37]. When there is more than $35 \%$ identity in a segment of 80 or more amino acids, immunoglobulin E (IgE) cross-reactivity between the newly expressed protein and a known allergen should be considered a possibility [38,39]. Based on this criterion, a full-length FASTA alignment was done using three different databases to determine the potential allergenicity of the expressed Mut2 protein (Table 7). The results showed that the Mut2 protein has potential allergenicity as evidenced by the $\%$ identity with the known allergens on the databases. In the first three databases, two groups of allergens were found to have more than $35 \%$ identity with the Mut2 protein, and these were Lens culinaris allergens (56-57\%) and Arachis hypogaea allergens (48-49\%). According to the Allergen Database for Food Safety, in addition to the previous groups of allergens, Lupinus angustifolius conglutin beta was also found to match the criteria with 56\% identity with the Mut protein. In a study by Torio et al. (2011) [11], 55\% identity was found in all mutant proteins with Lens culinaris allergen Len C 1.0102. Additionally, based on UniProt and Allergome database queries, sequences matching up to $99.8 \%$ were found in species, including Vigna radiata, Vigna angularis, Glycine soja, and Glycine max. Bioinformatics analysis showed that the mutated $8 \mathrm{~S} \alpha$ globulin can be a potential allergen; however, in vitro and in vivo experiments are still needed to further validate these findings.

Table 7. Analysis of the allergenic potential of Mut2 $8 \mathrm{~S} \alpha$ globulin using full-length FASTA alignment.

\begin{tabular}{lcc}
\hline \multicolumn{1}{c}{ Database/Allergens } & \% Identity & E-Value \\
\hline Allermatch [29] & & \\
Lens culinaris Allergen Len c 1.0102 & 57.00 & $1.9 \times 10^{-51}$ \\
Lens culinaris Allergen Len c 1.0101 & 56.40 & $2.7 \times 10^{-51}$ \\
Arachis hypogaea Allergen Ara h 1, clone P17 & 50.60 & $4.4 \times 10^{-31}$ \\
Arachis hypogaea Allergen Ara h 1, clone P41B & 49.20 & $2.8 \times 10^{-26}$ \\
Arachis hypogaea Ara h 1 allergen & 48.40 & $1.8 \times 10^{-17}$ \\
AllergenOnline [27] & & \\
Lens culinaris Allergen Len c 1.0102 & 57.00 & $2.2 \times 10^{-60}$ \\
Lens culinaris Allergen Len c 1.0101 & 56.40 & $3.2 \times 10^{-60}$ \\
Arachis hypogaea Allergen Ara h 1, clone P17 & 50.60 & $1.1 \times 10^{-36}$ \\
Arachis hypogaea Allergen Ara h 1, clone P41B & 49.20 & $4.5 \times 10^{-31}$ \\
Arachis hypogaea Ara h 1 allergen & 48.40 & $8.6 \times 10^{-21}$ \\
ADFS [26] & & \\
Lupinus angustifolius conglutin beta & 56.20 & $6.2 \times 10^{-91}$ \\
Lens culinaris Allergen Len c 1.0102 & 56.80 & $4.1 \times 10^{-64}$ \\
Lens culinaris Allergen Len c 1.0101 & 55.90 & $5.5 \times 10^{-64}$ \\
Arachis hypogaea Allergen Ara h 1, clone P17 & 50.60 & $1.5 \times 10^{-38}$ \\
Arachis hypogaea Allergen Ara h 1, clone P41B & 49.80 & $3.5 \times 10^{-33}$ \\
Arachis hypogaea Ara h 1 allergen & 48.50 & $4.0 \times 10^{-21}$ \\
\hline
\end{tabular}


Table 7. Cont.

\begin{tabular}{lcc}
\hline \multicolumn{1}{c}{ Database/Allergens } & \% Identity & E-Value \\
\hline UniProt [30] & & \\
Beta-conglycinin, beta chain-like precursor (Vigna radiata var. radiata) & 99.1 & 0.0 \\
Uncharacterized protein (Vigna angularis var. angularis) & 92.4 & 0.0 \\
Beta-conglycinin, beta chain-like isoform X1 (Vigna radiata var. radiata) & 91.0 & 0.0 \\
Beta-conglycinin, beta chain-like precursor (Vigna radiata var. radiata) & 89.8 & 0.0 \\
Beta-conglycinin, beta chain-like (Vigna radiata var. radiata) & 93.6 & 0.0 \\
Allergome [31-33] & & \\
10100 Vig r 2.0201—(uniport:B1NPN8 (454)) & 99.8 & $1.3 \times 10^{-147}$ \\
10099 Vig r 2.0101—(uniport:Q198W3 (453)) & 95.9 & $1.4 \times 10^{-124}$ \\
10074 Gly s 5-(uniport:A3KEY7) & 91.8 & $7.3 \times 10^{-103}$ \\
5818 Gly m 5.0201-(uniport:Q9FZP9) & 91.8 & $7.3 \times 10^{-103}$ \\
5816 Gly m 5-(uniport:Q7XXT2) & 91.8 & $8.3 \times 10^{-103}$ \\
\hline
\end{tabular}

Based on the epitope search conducted in ADFS [26] and AllerBase [28], the IIAEK peptide matched the Bos $\mathrm{d} 5$ epitopes (Table 8), which was expected since the source of this peptide was the bovine milk protein, $\beta$-lactoglobulin [8]. Previous studies have shown that structural similarity of allergens, specifically their IgE-binding epitopes, plays a critical role in cross-reactivity [38,39].

Table 8. Potential allergenicity analysis of the IIAEK peptide with existing IgE-binding epitopes.

\begin{tabular}{|c|c|c|c|}
\hline $\begin{array}{l}\text { Database/ } \\
\text { Source }\end{array}$ & Epitope Match & Amino Acid Sequence & Type \\
\hline \multicolumn{4}{|l|}{ ADFS [26] } \\
\hline \multirow[t]{3}{*}{$\begin{array}{c}\text { Bos taurus } \\
\text { (bovine milk) }\end{array}$} & $\begin{array}{c}\text { Bos_d_5.0101|EP00143|R00286.0 } \\
\text { associated with the reactive } \\
\text { patients' group }\end{array}$ & $\begin{array}{l}\text { LQKWENDECAQKK } \\
\text { IIAEKTK }\end{array}$ & Linear \\
\hline & $\begin{array}{c}\text { Bos_d_5.0101|EP00150|R00286.0 } \\
\text { detected as } 3 \text { contiguous spots in } \\
\text { peptide microarray }\end{array}$ & $\begin{array}{c}\text { ECAQKKIIAEKTKIPAVFKID } \\
\text { ALNEN }\end{array}$ & Linear \\
\hline & Bos_d_5.0101|EP00074|R00286.0 & AQKKIIAEKTKI & Linear \\
\hline \multicolumn{4}{|l|}{ Allerbase [28] } \\
\hline \multirow{2}{*}{$\begin{array}{l}\text { Bos taurus } \\
\text { (bovine milk) }\end{array}$} & Bos d 5.0101 & AQKKIIAEKTKI & Linear \\
\hline & Bos d 5.0102 & $\begin{array}{l}\text { LQKWENDECAQKK } \\
\text { IIAEKTK }\end{array}$ & Linear \\
\hline
\end{tabular}

\section{Discussion}

The main objective of this study is to introduce modifications in the $8 \mathrm{~S} \alpha$ globulin of mung bean, leading to the expression and release of the hypocholesterolemic peptide, IIAEK. Using protein engineering, specifically site-directed mutagenesis, base mutations were successfully introduced to the wild-type plasmid, producing a mutant plasmid capable of expressing the IIAEK bioactive peptide. In silico 3D modeling and prediction of the mutant $8 \mathrm{~S} \alpha$ globulin indicated high homology $(97.23 \%)$ and similarity $(98.49 \%)$ with the wild-type template. Protein determination confirmed the expression of the mutant $8 \mathrm{~S} \alpha$ globulin. Purification and digestion of protein further validated the expression and stability of the mutant $8 \mathrm{~S} \alpha$ globulin. The identification of released IIAEK peptide was successfully done using LC-MS.

Both Wt and Mut2 hydrolysates exhibited bile acid binding activity using the UPLC method. The binding capacity exhibited by the Wt digests still needs further proof to identify what factor contributes to this effect. Yao et al. (2014) [40] reported that mung bean proteins exhibited hypocholesterolemic activity, as evidenced by decreased plasma cholesterol and triacylglycerol in the experimental groups with mung bean supplementation. A recent study by Lopes et al. (2018) [41] found reduced plasma concentrations of total cholesterol and non-(high density lipoprotein)HDL 
cholesterol, increased fecal cholesterol excretion, and reduced levels of asparagine aminotransferase and alanine aminotransferase enzymes in the liver, which suggested that mung beans exhibited significant hypocholesterolemic activity. The identified binding capacity of the Mut 2 hydrolysates was comparable to the $\beta$-lactoglobulin tryptic hydrolysate and casein tryptic hydrolysate which showed $47.4 \%$ and $35.1 \%$ binding capacity, respectively, as reported by Nagaoka et al., 2001 [8]. Their study suggested that the inhibition of micellar solubility of cholesterol, which causes the suppression of cholesterol absorption by a direct interaction between cholesterol mixed micelles, and the $\beta$-lactoglobulin tryptic hydrolysate in the jejunal epithelia is part of the underlying mechanism of the hypocholesterolemic action of IIAEK. They speculated that IIAEK (lactostatin) may have influenced the reduction in cholesterol activity by increasing the amount of vesicular cholesterol rather than that of micellar cholesterol. Nonetheless, in a recent review by the same author [42], it was shown that the cholesterol-lowering peptide (lactostatin: IIAEK) operates via a new regulatory pathway in the calcium-channel-related mitogen-activated protein kinase (MAPK)-signaling pathway of cholesterol degradation. This, along with various in vitro and in vivo assays, points to the mechanism of IIAEK which involved the transactivation of the CYP7A1 gene ( $7 \alpha$-hydroxylase), which is the rate-limiting step of cholesterol degradation or bile acid synthesis. Further experiments are necessary to validate this new mechanism and compare it with other previously proposed mechanisms.

In silico analysis showed that lactostatin is a part of epitopes found in existing allergens which may indicate its potential allergenicity. Allergens found in proteins have specific immunological characteristics that play important roles in their allergenicity. Allergens bind to immunoglobulin $\mathrm{E}$ (IgE) through two or more IgE-binding epitopes or antigenic determinants, which lead to cross-linking of allergens with basophils and mast cells. Clinical symptoms of allergy can be elicited by IgE-binding epitopes, which can be characterized as linear or conformational $[43,44]$. The lactostatin peptide was found to be part of a linear epitope, which is a sequence of contiguous amino acids that are recognized by IgE antibodies. Conformational epitopes, on the other hand, comprise amino acids that line up because of the tertiary structure of an allergen. Linear or sequential epitopes have been suggested to be more important in food allergens because food proteins are usually cooked, leading to heat denaturation and alteration in tertiary structure, and digested in the gastrointestinal tract, leading to further alteration and break-up of the tertiary structure before reacting with the immune system [45]. Pentapeptides, such as IIAEK, are considered as a minimal immune determinant in humoral and cellular immune recognition because a group of five amino acids is capable of immunogenicity and antigenicity [46]. Although the IIAEK pentapeptide was found to exist in different epitopes and proteins, these still have completely different conformations. The mutated IIAEK in this paper was found to have change in secondary structure from random coil to $\alpha$-helix. In other proteins, however, the same peptide may be a part of a $\beta$-strand or a random coil structure [47]. The pentapeptide conformation in the intact protein is based on the structure of the amino acids that surround IIAEK, thus it may be entrenched in the protein folds or exposed on the protein surface $[47,48]$. Antibodies produced against one pentapeptide do not recognize all the possible pentapeptide conformations but interact with just one or a few of the pentapeptide binding sites based on the flanking amino acids [49-51]. IIAEK being part of existing allergenic proteins and epitopes confirms its potential allergenicity.

\section{Conclusions}

This study showed the great potential of food protein engineering in improving the nutritional value of common food crops, such as mung bean. Having successfully mutated the lactostatin peptide into the $8 \mathrm{~S} \alpha$ globulin, this product can be further developed into a food supplement or additive for use by individuals suffering from high cholesterol levels.

Supplementary Materials: The following are available online at http://www.mdpi.com/2076-3417/10/24/8787/s1, Figure S1: Chromatogram of the 24-h digests of Wt and Mut2 8S $\alpha$ globulin using LC-MS, Figure S2: Spectra of the 24-h digests of $\mathrm{Wt}$ and Mut2 $8 \mathrm{~S} \alpha$ globulin using LC-MS, Table S1: Prediction of the stabilizing effect of mutations, Table S2: Bile acid-binding capacity of Wt and Mut2 $8 \mathrm{~S} \alpha$ globulin digests. 
Author Contributions: Conceptualization, M.A.T.; formal analysis, M.C.G. and M.A.T.; investigation, M.C.G. and M.A.T.; Methodology, M.C.G.: resources, A.L., W.H. and M.A.T.; supervision A.L., W.H. and M.A.T.; visualization, M.C.G.; writing-Original draft preparation, M.C.G., M.A.T., A.L., W.H. and L.Y.U.; writing-Review and editing, M.C.G., M.A.T., A.L., W.H. and L.Y.U. All authors have read and agreed to the published version of the manuscript.

Funding: This study was funded by the Emerging Interdisciplinary Research Program, Office of the Vice President for Academic Affairs, University of the Philippines, EIDR C05-002.

Acknowledgments: The authors acknowledge the Process Biochemistry Laboratory (PS B-307)—University of the Philippines Los Baños. Special thanks to Evelyn Mae T. Mendoza, Asuncion K. Raymundo, Ernesto J. Del Rosario, Carla B. Dimalanta and Gisela P. Concepcion.

Conflicts of Interest: The authors declare no conflict of interest.

\section{References}

1. Espin, J.C.; Garcia-Coneas, M.T.; Tomas-Barberan, F.A. Nutraceticals: Facts and fiction. Phytochemistry 2007, 68, 2986-3008. [CrossRef] [PubMed]

2. Tang, D.; Dong, Y.; Ren, H.; Li, L.; He, C. A review of phytochemistry, metabolite changes, and medicinal uses of the common food mung bean and its sprouts (Vigna radiata). Chem. Cent. J. 2014, 8, 4. [CrossRef] [PubMed]

3. Anwar, F.; Latif, S.; Przybylski, R.; Sultana, B.; Ashraf, M. Chemical composition and antioxidant activity of seeds of different cultivars of mung bean. J. Food Sci. 2007, 72, 503-510. [CrossRef] [PubMed]

4. Mendoza, E.M.T.; Adachi, M.; Bernardo, A.E.N.; Utsumi, S. Mungbean [Vigna radiate (L.) Wilczek] Globulins: Purification and Characterization. J. Agric. Food Chem. 2001, 49, 1552-1558. [CrossRef] [PubMed]

5. Yi-Shen, Z.; Shuai, S.; Fitzgerald, R. Mung bean proteins and peptides: Nutritional, functional and bioactive properties. Food Nutr. Res. 2018, 62. [CrossRef]

6. Turanli-Yildiz, B.; Alkım, C.; Petek, Ž.; Turanl1-Yıldız, B. Protein Engineering Methods and Applications. Protein Eng. 2012. [CrossRef]

7. Prak, K.; Maruyama, Y.; Maruyama, N.; Utsumi, S. Design of genetically modified soybean proglycinin A1aB1b with multiple copies of bioactive peptide sequences. Peptides 2006, 27, 1179-1186. [CrossRef]

8. Nagaoka, S.; Futamura, Y.; Miwa, K.; Awano, T.; Yamauchi, K.; Kanamaru, Y.; Tadashi, K.; Kuwata, T. Identification of Novel Hypocholesterolemic Peptides Derived from Bovine Milk $\beta$-Lactoglobulin. Biochem. Biophys. Res. Commun. 2001, 281, 11-17. [CrossRef]

9. Itoh, T.; Garcia, R.N.; Adachi, M.; Maruyama, Y.; Tecson-Mendoza, E.M.; Mikami, B.; Utsumi, S. Structure of $8 \mathrm{~S} \alpha$ globulin, the major seed storage protein of mung bean. Acta Crystallogr. Sect. D Biol. Crystallogr. 2006, 62, 824-832. [CrossRef]

10. Pires, D.E.; Ascher, D.B.; Blundell, T.L. DUET: A server for predicting effects of mutations on protein stability using an integrated computational approach. Nucleic Acids Res. 2014, 42, W314-W319. [CrossRef]

11. Torio, M.; Adachi, M.; Garcia, R.; Prak, K.; Maruyama, N.; Utsumi, S.; Tecson-Mendoza, E. Effects of engineered methionine in the $8 \mathrm{~s} \alpha$ globulin of mung bean on its physicochemical and functional properties and potential nutritional quality. Food Res. Int. 2011, 44, 2984-2990. [CrossRef]

12. Torio, M.; Itoh, T.; Garcia, R.; Maruyama, N.; Utsumi, S.; Tecson-Mendoza, E. Introduction of sulfhydryl groups and disulfide linkage to mung bean $8 \mathrm{~s} \alpha$ globulin and effects on physicochemical and functional properties. Food Res. Int. 2012, 45, 277-292. [CrossRef]

13. Power, O.; Fernández, A.; Norris, R.; Riera, F.; Fitzgerald, R.J. Selective enrichment of bioactive properties during ultrafiltration of a tryptic digest of $\beta$-lactoglobulin. J. Funct. Foods 2014, 9, 38-47. [CrossRef]

14. Olsen, J.V.; Ong, S.-E.; Mann, M. Trypsin Cleaves Exclusively C-terminal to Arginine and Lysine Residues. Mol. Cell. Proteom. 2004, 3, 608-614. [CrossRef]

15. Waterhouse, A.; Bertoni, M.; Bienert, S.; Studer, G.; Tauriello, G.; Gumienny, R.; Heer, F.T.; Beer, T.A.P.D.; Rempfer, C.; Bordoli, L.; et al. SWISS-MODEL: Homology modelling of protein structures and complexes. Nucleic Acids Res. 2018, 46, W296-W303. [CrossRef] [PubMed]

16. Bienert, S.; Studer, G.; Tauriello, G.; Waterhouse, A.; De beer, T.A.P.; Bordoli, L.; Schwede, T. The swiss-model repository-New features and functionality. Nucleic Acids Res. 2017, 45, 313-319. [CrossRef] [PubMed]

17. Guex, N.; Peitsch, M.C.; Schwede, T. Automated comparative protein structure modeling with SWISS-MODEL and Swiss-PdbViewer: A historical perspective. Electrophoresis 2009, 30, S162-S173. [CrossRef] 
18. Benkert, P.; Biasini, M.; Schwede, T. Toward the estimation of the absolute quality of individual protein structure models. Bioinformatics 2011, 27, 343-350. [CrossRef] [PubMed]

19. Bertoni, M.; Kiefer, F.; Biasini, M.; Bordoli, L.; Schwede, T. Modeling protein quaternary structure of homoand hetero-oligomers beyond binary interactions by homology. Sci. Rep. 2017, 7, 1-15. [CrossRef]

20. Ye, Y.; Godzik, A. Flexible structure alignment by chaining aligned fragment pairs allowing twists. Bioinformatics 2003, 19, ii246-ii255. [CrossRef]

21. Bernardo, A.E.N.; Garcia, R.N.; Adachi, M.; Angeles, J.G.C.; Kaga, A.; Ishimoto, M.; Utsumi, S.; Tecson-Mendoza, E.M. 8S Globulin of Mungbean [Vigna radiate (L.) Wilczek]: Cloning and Characterization of Its cDNA Isoforms, Expression inEscherichia coli, Purification, and Crystallization of the Major Recombinant 8S Isoform. J. Agric. Food Chem. 2004, 52, 2552-2560. [CrossRef] [PubMed]

22. Bradford, M.M. A rapid and sensitive method for the quantitation of microgram quantities of protein utilizing the principle of protein-dye binding. Anal. Biochem. 1976, 72, 248-254. [CrossRef]

23. Laemmli, U.K. Cleavage of Structural Proteins during the Assembly of the Head of Bacteriophage T4. Nat. Cell Biol. 1970, 227, 680-685. [CrossRef]

24. Hu, Y.-B.; Wang, Z.; Xu, S.-Y. Treatment of corn bran dietary fiber with xylanase increases its ability to bind bile salts, in vitro. Food Chem. 2008, 106, 113-121. [CrossRef]

25. Kongo-Dia-Moukala, J.U.; Zhang, H.; Claver, I.P. In Vitro Binding Capacity of Bile Acids by Defatted Corn Protein Hydrolysate. Int. J. Mol. Sci. 2011, 12, 1066-1080. [CrossRef] [PubMed]

26. Nakamura, R.; Teshima, R.; Takagi, K.; Sawada, J.-I. Development of Allergen Database for Food Safety (ADFS): An integrated database to search allergens and predict allergenicity. Kokuritsu Iyakuhin Shokuhin Eisei Kenkyujo Hokoku Bull. Natl. Inst. Health Sci. 2005, 123, 32-36. Available online: http://allergen.nihs.go.jp/ADFS/ (accessed on 5 December 2018).

27. Goodman, R.E.; Ebisawa, M.; Ferreira, F.; Sampson, H.A.; Van Ree, R.; Vieths, S.; Baumert, J.L.; Bohle, B.; Lalithambika, S.; Wise, J.; et al. AllergenOnline: A peer-reviewed, curated allergen database to assess novel food proteins for potential cross-reactivity. Mol. Nutr. Food Res. 2016, 60, 1183-1198. [CrossRef]

28. Kadam, K.; Karbhal, R.; Jayaraman, V.K.; Sawant, S.; Kulkarni-Kale, U. AllerBase: A comprehensive allergen knowledgebase. Database 2017, 2017, bax066. [CrossRef]

29. Fiers, M.W.E.J.; Kleter, G.; Nijland, H.; Peijnenburg, A.A.; Nap, J.-P.; Van Ham, R.C.H.J. Allermatch ${ }^{\mathrm{TM}}$, a webtool for the prediction of potential allergenicity according to current FAO/WHO Codex alimentarius guidelines. BMC Bioinform. 2004, 5, 133. [CrossRef]

30. The UniProt Consortium. UniProt: A worldwide hub of protein knowledge. Nucleic Acids Res. 2018, 47, D506-D515. [CrossRef]

31. Mari, A.; Rasi, C.; Palazzo, P.; Scala, E. Allergen databases: Current status and perspectives. Curr. Allergy Asthma Rep. 2009, 9, 376-383. [CrossRef]

32. Mari, A.; Scala, E.; Palazzo, P.; Ridolfi, S.; Zennaro, D.; Carabella, G. Bioinformatics applied to allergy: Allergen databases, from collecting sequence information to data integration. The Allergome platform as a model. Cell. Immunol. 2006, 244, 97-100. [CrossRef]

33. Mari, A.; Scala, E. Allergome: A unifying platform. Arb Paul Ehrlich Inst Bundesamt Sera Impfstoffe Frankf A M 2006, 95, 29-40. Available online: http://www.allergome.org/index.php (accessed on 25 October 2020).

34. Janson, J.C.; Rydén, L. Protein Purification: Principles, High-Resolution Methods, and Applications, 2nd ed.; John Wiley \& Sons: New York, NY, USA, 1997; p. 284.

35. Gasteiger, E.; Hoogland, C.; Gattiker, A.; Duvaud, S.; Wilkins, M.R.; Appel, R.D.; Bairoch, A. Protein identification and analysis tools on the expasy server. In The Proteomics Protocols Handbook; Humana Press: Totowa, NJ, USA, 2005.

36. Aalberse, R.C.; Akkerdaas, J.; Van Ree, R. Cross-reactivity of IgE antibodies to allergens. Allergy 2001, 56, 478-490. [CrossRef] [PubMed]

37. Popescu, F.-D. Cross-reactivity between aeroallergens and food allergens. World J. Methodol. 2015, 5, 31-50. [CrossRef] [PubMed]

38. McClain, S.U. Bioinformatic screening and detection of allergen cross-reactive IgE-binding epitopes. Mol. Nutr. Food Res. 2017, 61, 1600676. [CrossRef]

39. Maleki, S.J.; Teuber, S.S.; Cheng, H.; Chen, D.; Comstock, S.S.; Ruan, S.; Schein, C.H. Computationally predicted IgE epitopes of walnut allergens contribute to cross-reactivity with peanuts. Allergy 2011, 66, 1522-1529. [CrossRef] 
40. Yao, Y.; Hao, L.; Shi, Z.; Wang, L.; Cheng, X.; Wang, S.; Ren, G. Mung Bean Decreases Plasma Cholesterol by Up-regulation of CYP7A1. Plant Foods Hum. Nutr. 2014, 69, 134-136. [CrossRef]

41. Lopes, L.A.R.; Martins, M.D.C.D.C.E.; De Farias, L.M.; Brito, A.K.D.S.; Lima, G.D.M.; De Carvalho, V.B.L.; Pereira, C.F.D.C.; Conde-Júnior, A.M.; Saldanha, T.; Arêas, J.A.G.; et al. Cholesterol-Lowering and Liver-Protective Effects of Cooked and Germinated Mung Beans (Vigna radiata L.). Nutrients 2018, 10, 821. [CrossRef]

42. Nagaoka, S. Structure-function properties of hypolipidemic peptides. J. Food Biochem. 2018, 43, e12539. [CrossRef]

43. Matsuo, H.; Yokooji, T.; Taogoshi, T. Common food allergens and their IgE-binding epitopes. Allergol. Int. 2015, 64, 332-343. [CrossRef] [PubMed]

44. Pomés, A.; Chruszcz, M.; Gustchina, A.; Wlodawer, A. Interfaces between allergen structure and diagnosis: Know your epitopes. Curr. Allergy Asthma 2015, 15, 506. [CrossRef] [PubMed]

45. Lin, J.; Sampson, H.A. The role of immunoglobulin e-binding epitopes in the characterization of food allergy. Curr. Opin. Allergy Clin. Immunol. 2009, 9, 357-363. [CrossRef]

46. Kanduc, D.; Shoenfeld, Y. Inter-Pathogen Peptide Sharing and the Original Antigenic Sin: Solving a Paradox. Open Immunol. J. 2018, 8, 16-27. [CrossRef]

47. Kabsch, W.; Sander, C. On the use of sequence homologies to predict protein structure: Identical pentapeptides can have completely different conformations. Proc. Natl. Acad. Sci. USA 1984, 81, 1075-1078. [CrossRef]

48. Kabsch, W.; Sander, C.; Kabsch, C.S.W. Identical pentapeptides with different backbones. Nat. Cell Biol. 1985, 317, 207. [CrossRef]

49. Niman, H.L.; Houghten, R.A.; Walker, L.E.; Reisfeld, R.A.; Wilson, I.A.; Hogle, J.M.; Lerner, R.A. Generation of protein-reactive antibodies by short peptides is an event of high frequency: Implications for the structural basis of immune recognition. Proc. Natl. Acad. Sci. USA 1983, 80, 4949-4953. [CrossRef]

50. Wilson, I.A.; Haft, D.H.; Getzoff, E.D.; Tainer, J.A.; Lerner, R.A.; Brenner, S. Identical short peptide sequences in unrelated proteins can have different conformations: A testing ground for theories of immune recognition. Proc. Natl. Acad. Sci. USA 1985, 82, 5255-5259. [CrossRef] [PubMed]

51. Schulze-Gahmen, U.; Wilson, I.A. Monoclonal antibodies against an identical short peptide sequence shared by two unrelated proteins. Pept. Res. 1989, 2, 322-331.

Publisher's Note: MDPI stays neutral with regard to jurisdictional claims in published maps and institutional affiliations.

(C) 2020 by the authors. Licensee MDPI, Basel, Switzerland. This article is an open access article distributed under the terms and conditions of the Creative Commons Attribution (CC BY) license (http://creativecommons.org/licenses/by/4.0/). 